\title{
Erratum to: ribosomal protein and biogenesis factors affect multiple steps during movement of the Saccharomyces cerevisiae Ty1 retrotransposon
}

Susmitha Suresh ${ }^{1,3}$, Hyo Won Ahn², Kartikeya Joshi ${ }^{1}$, Arun Dakshinamurthy ${ }^{1,4}$, Arun Kannanganat ${ }^{1}$, David J. Garfinkel ${ }^{2}$ and Philip J. Farabaugh ${ }^{1 *}$

\section{Erratum}

Unfortunately, the original version of this article [1] contained an error. The author's name, 'Arun Kananganat', was spelt incorrectly. This can be found corrected in the author list above.

\section{Author details}

${ }^{1}$ Department of Biological Sciences and Program in Molecular and Cell Biology, University of Maryland Baltimore County, Baltimore 21250, MD, USA. ${ }^{2}$ Department of Biochemistry \& Molecular Biology, University of Georgia, Athens 30602, GA, USA. ${ }^{3}$ Present address: Division of Infectious Diseases, Department of Internal Medicine, Stanford University School of Medicine, Stanford 94305, California, USA. ${ }^{4}$ Present address: Department of Nanosciences and Technology, Karunya University, Karunya Nagar, Coimbatore 641 114, Tamil Nadu, India.

Received: 14 January 2016 Accepted: 19 January 2016

Published: 9 February 2016

\section{References}

1. Suresh S, Ahn HW, Joshi K, Dakshinamurthy A, Kannanganat A, Garfinkel DJ, et al. Ribosomal protein and biogenesis factors affect multiple steps during movement of the Saccharomyces cerevisiae Ty1 retrotransposon. Mobile DNA. 2015;6:22.

* Correspondence: farabaug@umbc.edu

Submit your next manuscript to BioMed Central and we will help you at every step:

- We accept pre-submission inquiries

- Our selector tool helps you to find the most relevant journal

- We provide round the clock customer support

- Convenient online submission

- Thorough peer review

- Inclusion in PubMed and all major indexing services

- Maximum visibility for your research

Submit your manuscript at

www.biomedcentral.com/submit 